\title{
A CONTRIBUTION OF THE SO.CALLED TELEPHONE DEAPNESS
}

\author{
By \\ S. KUROYANAGI \\ From the Department of Otolaryngology, Nippon Medical School
}

(Director: Prof. T. Daito)

In order determine whether telephone deafness was caused by scoustio trauma or not, an efficiency of the telephones, auditory fatigue of the telephone operators and some conditions under which they were apt to suffer from telephone deafness were studied.

The results obtained were as follow:

1. The frequency ranges of the telephones were from 200 to $4000 \mathrm{cps}$ and the level of its sensitivity was $65 \mathrm{db}$ at $1000 \mathrm{cps}$ and its sensitivity: deviation between at $300 \mathrm{cps}$ and at $2500 \mathrm{cps}$ was only $10 \mathrm{db}$. Therefore the sound pressure conducted to the ear of the operators was not over $70 \mathrm{db}$.

2. Of 914 telephone operators, $17.7 \%$ had hearing impairment.

3. In the operators with normal hearing the level of auditory fatigue against one day work was within $15 \mathrm{db}$ and immunity from auditory fatigue was obtained with the increase of the years for which they worked. In operators who worked over 4 years the auditory fatigue was located in 500 to $2000 \mathrm{cps}$. And in them who had worked over 8 years it was not recognized. On the other hand, in operators with telephone deafness it was from 15 to $30 \mathrm{db}$.

4. As the reuslts of the function tests, of the automatic nervons system, vagotonia was observed frequentlv in the apprentices and operators with normal hearing, followed by the operators with deafness. Especially the difference of its frequency between in the operators with normal and impaired hearing was remarkable. Sympatheticotonia, changeable vagotonia and non-reaction were obserevd frequently in them with deafness.

5. As compaired with the operators with normal hearing, in the cases with deafness the irregular cellularityand absorption of the mastoid cells were more remarkable.

6. By 'using Sawada's urinalysis method, the values of vitamin-B in blood were measured. Thirty percent of the cases with normal hearing and $62 \%$ of them with deafness were foued to be deficient in vitamin- $B_{1}$ :

7. It is resonable to presume that telephone deafness is not caused by directors. As based on thase findings, it must be distinguished from usual occupational deafness.

\section{所謂電話難聴（Telephone Deafness）に関する研究補遺}

日本医科大学耳鼻咽喉科学教室（主任：大藤放三教授）

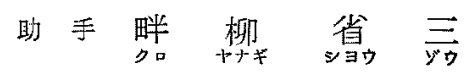

緒言

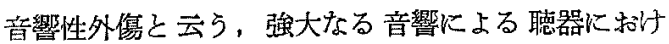
万障㥂に関寸る研究は，19 世紀来より，St. V. Stein (1886) を始めとし, Wittmaack 門下の吉汼 (1909),
Popoff（1925）の先人上り，最近に堆いては河由教授の 宿題報告 (1955) まで幾多の先翼によつて臨床的並に動 物実験的火追及されているが，比較的微弱な，ないし中

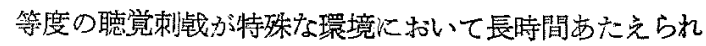


た場合の聴力障碍，例兑ば笔話交换手の聴力障碍などに 関与る研究は青木 (1953), 内海 (1952), Tauno palva (1957)，荻野（1958）等の総括的な報告以外㵊近にお ける施設の完倩した電話局炕特ける系維的な研究は未だ なされていない。ここにおいて進歩した近代的施設の下 で業務化従事する電話交渙手の聴力障得が，いかなる状 件あるいはいかなる環境において起り易いかを追及す る目的で次の項目に従つて東京市外電話局を中心として 観察を行い，いさ」かの知見を得たのでこつに報告す る.

研究項目 :

1) 笔話器の性能について

2) 聴力障碍の状態について

3）交热手の聴覚疲労に関する成縜:

4）聴力障碍之自律神経江関する成積

5) 聴力障碍と側頭骨含気䗋筒との関係

6) 聴力障碍とVitamin $B_{1}$ との関你

\section{1) 電話器の性能について}

電話難聴を研究するには先ず交换手の便用する電話器 の特性を調べる必要があると考充，交換用受話器につい て調查した，即ち，現在日本電信電話公社の規定による 電話交換用受話器は，R-4 型受話器である．これには 次の 3 点について特に侤虑されている。

（イ）音声に必要な 周波数帯域で伝送特性が 良いこ z.

(ロ）電話音量変換能率が高いこと、

（ハ）品質一様で量産可能なること.

音声のもつ周波数箸囲は大体 $100 \mathrm{cps}$ 7000 cps で特 に $300 \mathrm{cps} \sim 3000 \mathrm{cps}$ の範团が 重要である. 又この範团 で急激な山や谷がなく，感度が平坦でであることが歪を 少くすること〉なる. (旧 3 号型では $1000 \mathrm{cps}$ に急激な 山があり所謂電話声になる) 又音量は普通の会話状態で は会話人は $\mathrm{Im}$ 離れて相対することつして，この時の 送話者の口唇から $3 \mathrm{~cm}$ の距離で $94 \mathrm{db}$ (10 $\mu \mathrm{bar}$ ) 受話 者の位置で $64 \mathrm{db}(\mathrm{db}=0.0002 \mu \mathrm{bar})$ の音圧が 発生し ていると云われている．従つて電話を用いた時も（送受 器をにぎり耳に当てた時， 口唇から約 $3 \mathrm{~cm}$ のところに 送話口がくるょうにしてあるので），自然に（普通に）話 したとき普通の音量で聞光，特に大声を出さなくてる良 いことが最良の条件である。

普通の通話状態を実現した標濩通話柔の正調通話レス ポンス特性の高い周波数成分を除去すると明瞭度が低下 する.この関係を音節明膫度をバロメーターとし，低域
第 1 表 標集通話（低域 3波）系の带域上 利得についての明嘹度曲瑔

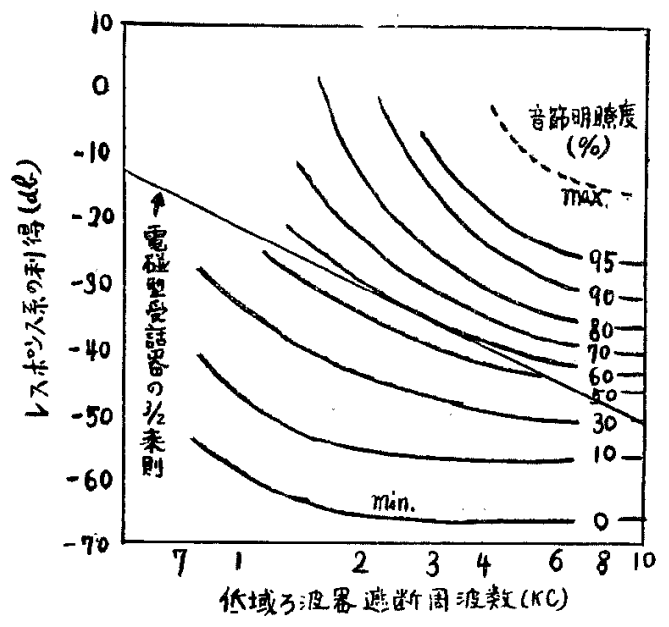

㴔波器の遮断周波数とレスポンス采の利得との関俰を図 に示すと第 1 表の如くである.

電話䒺で羍し得る最高明瞭度を得るには少くとも 400 cps 变での帯域が必要で系の利得としては Odb 以下K は下げられないこと, 文周波数帯域を $7000 \mathrm{cps}$ 以上ま で㧓げても柔利得で $-12 \mathrm{db}$ が限度であることが分る。

電話器使用される電磁型受話器の設計条件について は，自白度 1 のさよりる自由度 2 のときの方が周波数 带域が多少広くなるが，特性のバラッキが大きくなり， 一様の品質量産が困難であるので受話器ニニットとして は自由度1採用し，この状態の感度周波数特性規定 している. 自由度 1 とすると, 受話器の伝送周波数带域 幅々感度との関保は, 電磁型受話器の安定度（㣫撃等に よつて振動板が磁栖面に押しつけられても磁力によつて 吸引されることなく正常位置に回復する力の程度を示 しここれが小さい程感度は上るが吸引され易くなるる 一定とすると $3 / 2$ 乗則が成り立ち，例えに゙帯域幅を2 倍 にすると $20 \log _{10} 3 / 2=9 \mathrm{db}$ だけ下ることになる。

第 1 表に上り，音節明膫度 $60 \%$ （峃音明膫度 $80 \%$ ， 章句明膫度 $98 \%$ に相当する）が電話回線に許された最 低の通話品質とすると，2000 3000 cps が最も設計上有 利でありこれょり低くても文高くても明膫度は下る絬 果になる。以上の結果受話器は $2500 \mathrm{cps}$ 主での周波数 を伝送し得るように設計され，受話器ニニットの規格と して 300 2500 cps の感度偏差（この闁の感度の最大值 と最小值の差）を決为，Rー4 型では 10db と決つた（第

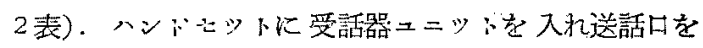




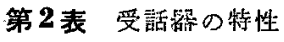

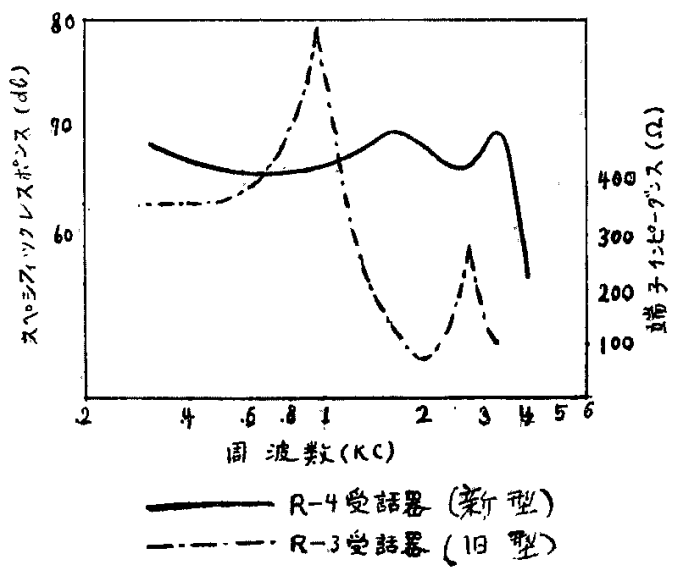

付けると穴の効果で带域は 4000 cps 迄伸びる。昍3号 型受話器では $1300 \mathrm{cps}$ が带域である。この带域を2 倍 にすると感度が約 9db 低下することになるが，この低 下防止するように設計されたのが R-4 型受話器であ り，感度公称値 $65 \mathrm{db}$ とした，この公称値とは $1000 \mathrm{cps}$ の周波数に沶いてのことである... 製作上; 検查上のバラ ッ丰考慮して規格は 60db 以上飞泆められている。 な打量産状況では $62 \mathrm{db}$ 以下のわのは皆血であり，63〜 $65 \mathrm{db}$ の中沉ある.

受話器の感度は大きい忹ど良いわけであるが，路線の 撌先が小さいときには音量恃大きすきることになり，そ れを調節するために自動音量摆節绫置が施されている。 又会話音の他代電話器プラグ差込によるクリック音の 発生を交换業菻中にみるが，現在ではクリンク電流の Peak 制限するた文に，バリスタ一回路が交换器仗取 付けられて郝り，シッック音は極るて小さく，音量，不 快感汇刘しては問題にならない。

\section{2）聴力障碍の状態について}

そ(か）アンケートによる調查：

東京市外電話局電話交换手 1863 名について 次の 事項 を調查した。
(1) 左右いずれの耳に受話器を当てるか.
(2) 耳鸣の有無.
(3) 交換業務終了後化る耳の王迫感の有舆.
(4) 效換業務終了後にまで残万耳痛の有無:
(1) の事項に刘しては:

$\begin{array}{ll}\text { 左耳のみ使用 } & 528 \text { 名 } \\ \text { 右耳年健用 } & 606 \text { 名 } \\ \text { 峏側交代倠用 } & 650 \text { 名 }\end{array}$

大体三等分せられた。

(2) の事項に対しては:

a) 耳鳴出現率

\begin{tabular}{|c|c|c|c|}
\hline 就業年 眼 & 獾查人員 & 出現人貝 & 百 分率 \\
\hline 2 年 & 247 名 & - 17 名 & $6.8 \%$ \\
\hline 3 年 & 206 名 & 14 名 & $6.7 \%$ \\
\hline 4 年 & 175 名 & 14 名 & $8.0 \% 6$ \\
\hline 5 年 & 285 名 & 31 名 & $10.8 \%$ \\
\hline 6 年 & 227 名 & 16 名 & $7.0 \%$ \\
\hline 7 年 & 105 名 & 13 名 & $11.9 \%$ \\
\hline 8 年 & 229 名 & 37 名 & $16.1 \%$ \\
\hline 9 年 & 170 名 & 13 名 & $7.6 \%$ \\
\hline 10 年 & . 57 名 & 10 名 & $17.5 \%$ \\
\hline 11 年 & 43 名 & 7 名 & $16.2 \%$ \\
\hline 12 年 & 119 名 & 9 名 & $7.5 \%$ \\
\hline 詝 & 1853 名 & 181 名 & $9.7 \%$ \\
\hline
\end{tabular}

1863 名の調查人員に剂して 181 名， $9.7 \%$ の百分率と なつた：就業年限と耳喺出現率との関俰恃，就業年限 7

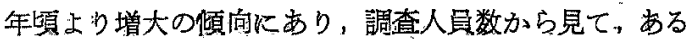
いは乞の訴へ方の程度からして幾分の疑義山あるが；市 る程度の增大傾向はあると云い得る。

耳鳴の分類については，岩崎 $\mathbf{S}_{\mathbf{A}-1}$ オージォメーター にて周波数測定を行つた. 各人の耳㩔の高低をオージォ メーダーの各周波数にあてはめて見ると大体次の如くで ある。

b) 耳鳴の測定：

$\begin{array}{rrr}250 \mathrm{cps} & 13 \text { 名 } & 8 \% \\ 500 \mathrm{pss} & 11 \text { 名 } & 7 \% \\ 800 \mathrm{cps} & 9 \text { 名 } & 6 \% \\ 1000 \mathrm{cps} & 18 \text { 名 } & 11 \% \\ 200 \mathrm{cps} & 3 \text { 名 } & 2 \% \\ 3000 \mathrm{cps} & 6 \text { 名 } & 4 \% \\ 4000 \mathrm{cps} & 18 \text { 名 } & 11 \% \\ 6000 \mathrm{cps} & 20 \text { 名 } & 13 \% \\ 8000 \mathrm{cps} & 60 \text { 名 } & 38 \%\end{array}$

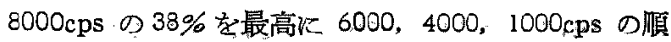
となつている。

（3）の事項に対しては:

1863 名中 250 名の圧迫感の訴竞があり，細分すれば

2時間以内消光るもの 155 名 $62 \%$ ，

2 時間以上 6 時間以内 $\quad 83$ 名 $33.2 \%$ 


\begin{tabular}{|c|c|}
\hline 6 洔間以上残存の すの & 12 名 \\
\hline 棓 & \\
\hline
\end{tabular}

大部分は 2 時問以内に圧迫感悄完るが，極く小数の 4.8\%飞括いては，6時間以上子続いた。

(4) の事項関しては:

1863 名中，282 名の耳痛を訴光て括り，15.1\% と比䡆 的多い。

以上のアンケートによつても交势業務が聴覚に何らか の影響を及淁すことが分つた。

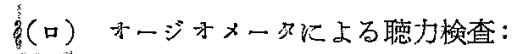

岩崎 $\mathrm{S}_{\mathrm{A}^{-1}}$ 型オージオメーターを使用し，規定防音 室において，250，500，1000，2000，4000，8000cps の6 筒所の 周波数に执いて 耐側気導㯖力検查を行い，30db

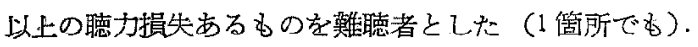

対照 (a) 交煥業務中出側耳を交代に使用せるるの 250 名

（b）交推業務中只一侧耳のみ文使用せるもの.. .914名

検查湤行方法は，交換業務に入る前，又は非番の日と し，業務による聴覚に及ぼす影響を避けた，対象 1)の 場合は，250名中， $30 \mathrm{db}$ 以上の聴力損失例 12 名，(4.8 \%) 19 耳あり分類すると，

$\begin{array}{ll}\text { 水平型: } & 2 \text { 耳 } \\ \text { 急傾型: } & 4 \text { 耳 } \\ \text { 桷頋型: } & 3 \text { 耳 } \\ \operatorname{dip} \text { 型: } & 9 \text { 耳 } \\ \text { 《型: } & 1 \text { 耳 }\end{array}$

以上の聴力像を是した，乙かし禹側耳難聴の場合，又

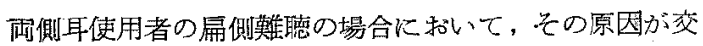

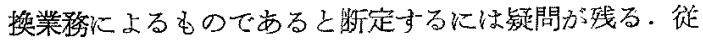
つて今回の研究に䏡いては，これらの症例は電話交挨手 の聴力障碍例上り全部除去した，爾微電話䨄聴として追 及した対照は，(b) の交換業務中一側の耳のみを保用し つづけた例だけであり，難聴者としだのは使用耳の方の み㶤起きた扁側難㗜者である。従って他側には聴力損失 を認めない者である。

対照 (b) の難䏇率:

$\begin{array}{rrrr}\text { 就業年限 } & \text { 調查人員 } & \text { 難眲者 } & \text { 百分率 } \\ \text { 2 4 4 年: } & 300 \text { 名 } & 25 \text { 名 } & 8.3 \% \\ \text { 4 7 年: } & 302 \text { 名 } & 55 \text { 名 } & 18.2 \% \\ 7 \text { 年以上: } & 312 \text { 名 } & 82 \text { 名 } & 26.2 \% \\ \text { 計 : } & 914 \text { 名 } & 162 \text { 名 } & 17.7 \%\end{array}$
全体の平均値は. $17.7 \%$ となつている，今迄の諸家の
報告を見ると，

$\begin{array}{ll}\text { 青 木 辉 思: } & 26.4 \% \\ \text { 川 名 正 二: } & 6.0 \% \\ \text { 荻 野 昭 三: } & 8.96 \% \\ \text { Truno palvar : } & 15.8 \%\end{array}$

となつているが，青木（綼）をのでいて他の報告は症例

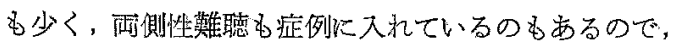
電話難聴としての平沟値とは云い難い，次化勤冴年限順 に追つて見ると，勤繶 4 年迄は 8.3\%，7 年迄は $18.2 \%$ ， 7 年以上は $26.2 \%$ 之勤務年限の增加と共に增加している が，電話交换手之云う職業が女子の結婚適令期に当つて

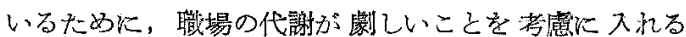
そ，その゙〉の数字を信用してい〉かどうか疑䦖が残る が，ある程度勤務年限に比例して增伈する傾向にある。

難聴々力像の分類：

$\begin{array}{lrr}\text { 水平型: } & 64 \text { 名 } & 39.6 \% \\ \text { 急傾型: } & 12 \text { 名 } & 7.4 \% \\ \text { 漸頃型: } & 39 \text { 名 } & 24.1 \% \\ \text { dip 型： } & 23 \text { 名 } & 14.1 \% \\ \text { 口4 型： } & 3 \text { 名 } & 1.8 \%\end{array}$

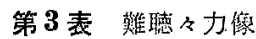

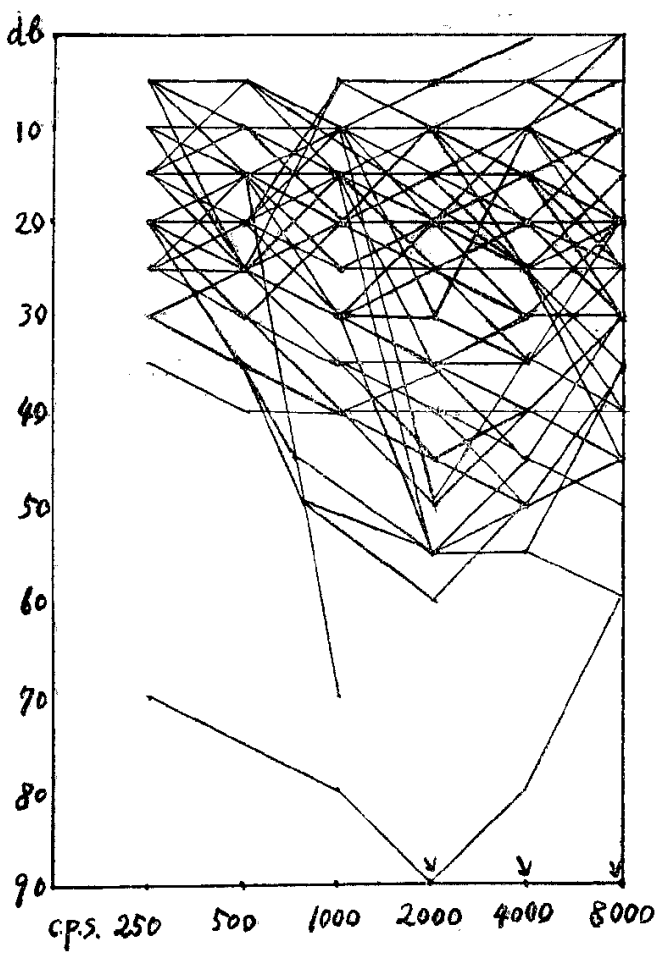




$\begin{array}{lll}\text { 메 羿： } & 6 \text { 名 } & 3.9 \% \\ \text { 不定型： } & 15 \text { 名 } & 9.2 \%\end{array}$

であり水平型最も多く，次いで漸傾型，dip 型, 不定型， 急傾型の順であつた。 dip 型については, 2000cps の dip が 7 名, $3000,4000 \mathrm{cps}$ 各 5 名, $6000 \mathrm{cps} 4$ 名, $1000 \mathrm{cps}$ 2 名であり，4000 cps の dip が特多いと云うことはな かつた。な叔急傾型1名，及び dip 型1名において， 交换業務停止後も1 年経過中に難聴の進行を見, 遂に全

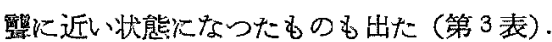

\section{3）電話交換手の聴覚疲労に関する 検査成績について}

騷音職場に就ける従業員の聴覚の感受性を目的とした 疫学訊験には de Mraé (1952), peyser (1952), Wilson (1950), Fox (1953) 等, 河村 (1955) に至るまでの短時 間，特定周波数の 80 120db 位の音刺㦸によるものが あるが，60db 位のしかも会話音を主体とした電話交換 手の聴覚疲労を追及する目的にはや〉場違の感なきをえ ない、そこで交尖手 1 日の仕沗量に対する聴覚疲労度を 湘定して見た。

測定区分は正常聴力者の勸枒年数を次の如くにし，電 話難聴者と対照した。
（1）抟続 1 3 年迄の正常聴力者
20 名
（口）勤続 4〜6 年迄の正常聴力者
20 名
（八）勤䋨 8 年以上の正常聴力者
20 名
(二) 電話蜼煷者
17 名

検查方浩：

交換業務に入る前，及び業務終了媛のホージォダラム による聴力曲線の損失度を疲労度とした。

成績:

（1）勤続 1～3 年泛の正常聴力者 (第 4 表)

表の如々 $125 \mathrm{cps} よ り 8000 \mathrm{cps}$ 迄大体平行した痕学 曲線を得，その損失の限度は $15 \mathrm{db}$ 以内であつた。

第 4 表 茈続 1 3 年迄の正常聴力者（20名） (设学度の表)

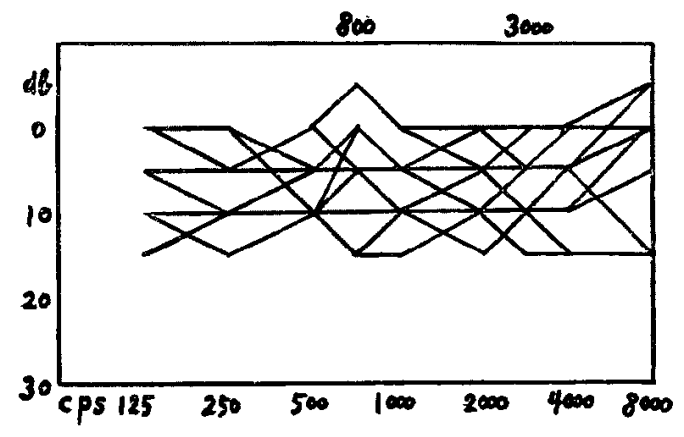

第 5 表 勤続 4 6 年迄の正常聴力者（20 名） (端労度の表)

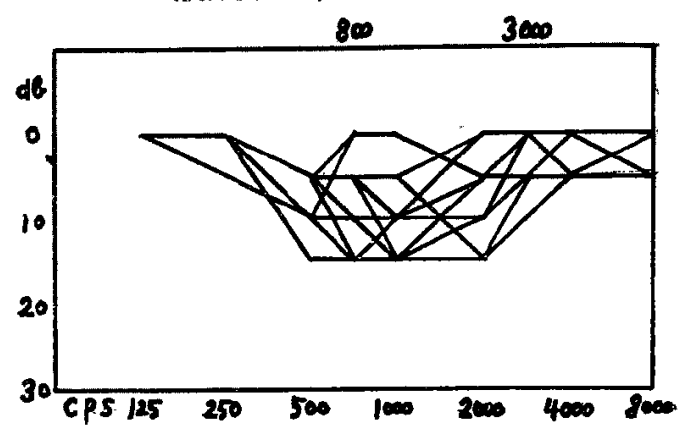

（只）勤続 4 6 年迄の正常聴力者（第 5 表）

主に $500 \mathrm{cps}$ より $2000 \mathrm{cps}$ 迄において疲学度が多く なり，125cps $8000 \mathrm{cps}$ の両側において収劒され舟型を

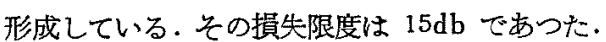

（八）勤続 8 年以上の正常聴力者

第6表の如く 125cps より 8000cpsに至るまで，5db 以内の疲労曲線が画かれた。これは即ち疲学の出ないる のと見て差支えない。

第 6 表 勤続 8 年以上の正常聴力者 (20 名) (疲学度の表)

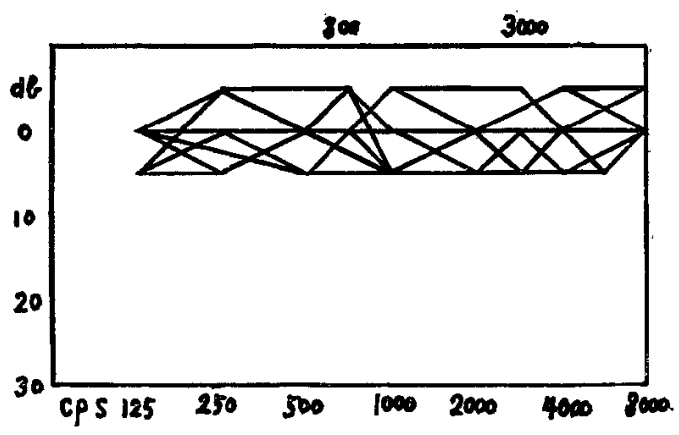

以上の 3 つグループの疲労曲線より, 勤務年限 3 年 以内に拈いては，125 8000 cps 迄各周波数均等に疲労 が現れ，次の 4〜6年汔に括いては 500〜2000cps に疲 労が限局され，更に 8 年以上になると，疲学の出現が見 られなくなる傾向があることが分つた。それは勤務年限 の增加と共に，什事に詨する「なれ」の現象のあらわ れによるものと思われる。なお 4〜6年汽の者に 500〜 $2000 \mathrm{cps}$ に疲労が限局されることは，同周波数間が会話 音の主要音域に相等することに鑑み，與味樑いことであ る. 以上は正常聴力者の場合である. 


\section{（二）難㙏交推手}

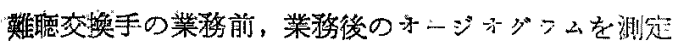
すると。

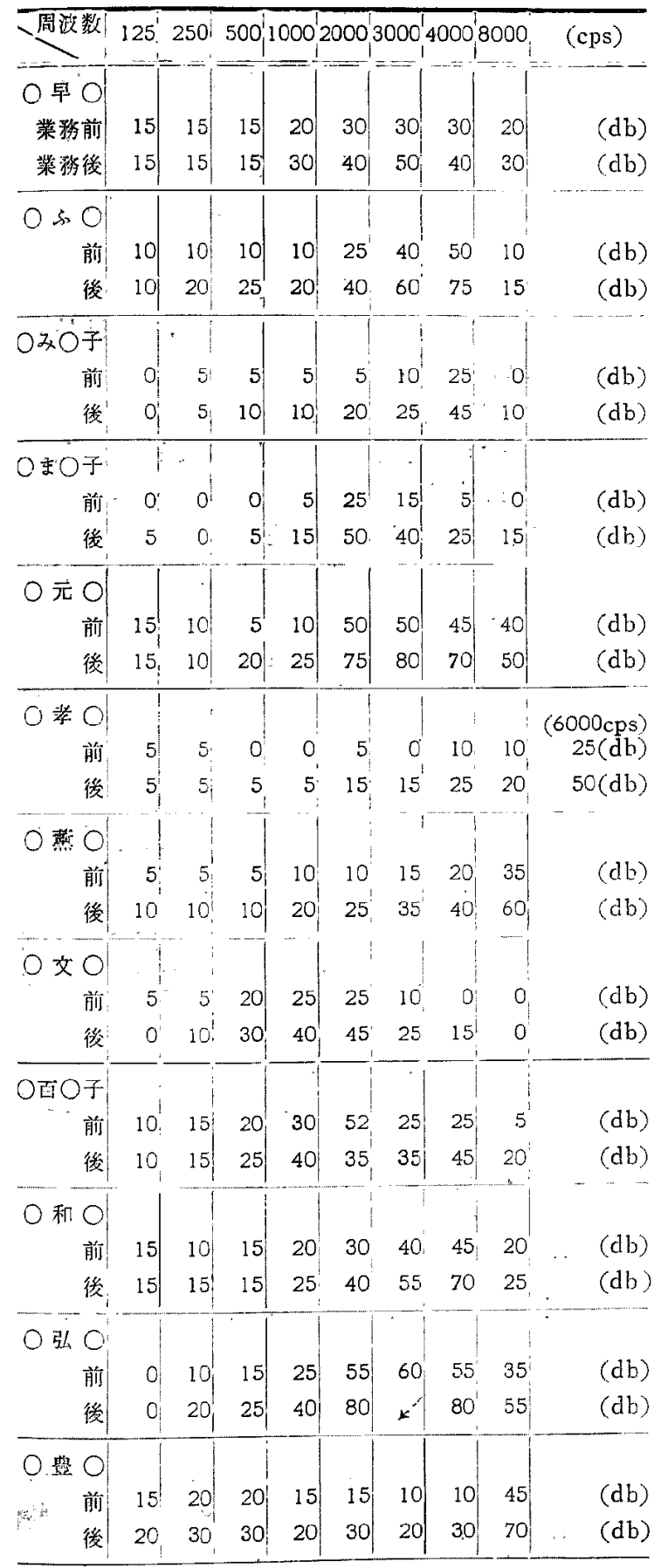
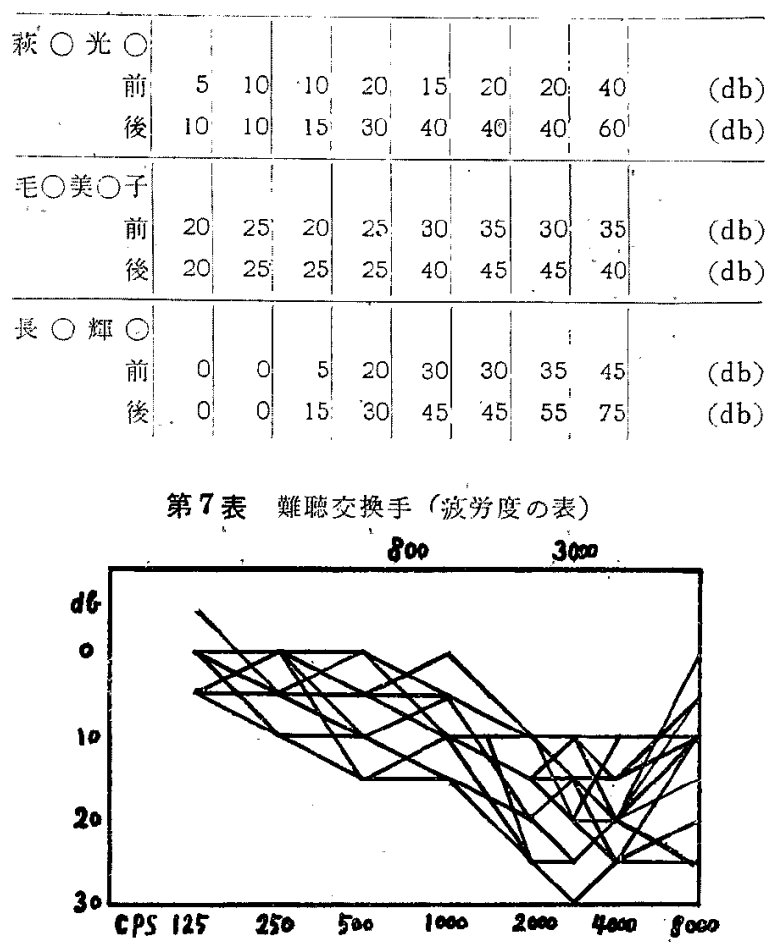

以上各例の充後の差孝疲等度として1枚のふージダ ○ム用紙に墨いてみると（第7表）

難聴を有する交換手の場合は，正常㯖力を有する资㮩

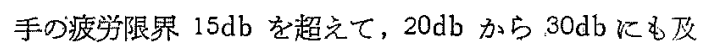

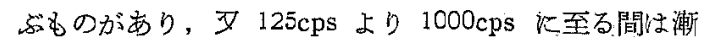
傾型の内でる損失曲線はや〉緩く，1000 cps より4000 cpsにおいては損失曲線は急傾型に近いものであり，就 中, 2000 4000cpsk执てては dip 型名認めら机, 明 らかに正常德力を有するるのとの鑑別ができる、即ち交

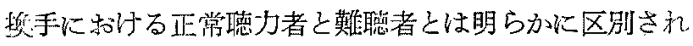

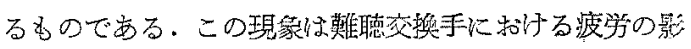

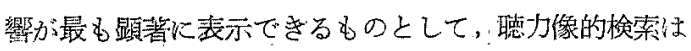

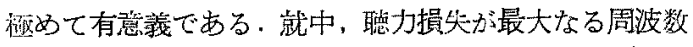
の場所は精神的疲学現象としての根拠を最も明確に表す ものとしてその洒值は大い。

\section{4) 電話難聴亡自律神経との関係}

聜器と自律神経との関你については，古くより記戴か あり，S. Istamanow “(1885) の音響作用と血管運䡃神

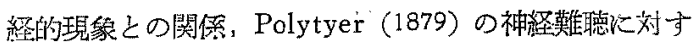
るピロカルピン療浩以来幾多の研究がなされた，頸部芳

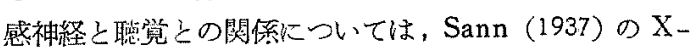


線放射療法，同じく河田（1950）の X- 線㸡射療法， 小沢 (1934)，柳原 (1934)，立木 (1944), Seymour, Tappin (1953)，Beickert (1953)，の頸部交感神経の

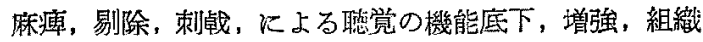
学的変成等の報告, Passe Leus (1954), Hoodland (1952) の頸部交感神経切除，遮断による に対する成續，又 Krejci，Rambo (1953) の頸部交感 神経刺战，遮断によるも聴覚に対する変化なしとの疑告 等あり, 全身的目种神経に作用する楽剂を使用しての研 究には, 仙石 (1930), 柳原 (1931), 川口 (1951), Wullstein (1953), Anderson (1953) の Adrenalin, Histamin, Physostigmin, Hydergin, Ginergin, Arterenol, 等を用いての音響性耳嗀反射, 聴覚疲学乃至順 応に関しての実験あり，最近に秋いては安達（1956）の 音響による自律神経の変化, 各種楽用使用に和ける自律 神経の変化, 聴覚の変化について報告し，艺の中で強大 音響による外傷性難聴者の自律神経の態度について, 自 律神経は副交感神経㻇掁型に傾〈傾向があると発表して いる.このような强大音響によらざる，電話交换手の場 合の如き，65db 以下の会話音による音刺㦸と，殿側の 耳に気導によつてのみ入ると云う特種な条件のもとにお ける自律神経の变化はいかなるものであるらか,この点 心就て追及して見た。

人体に和ける自律神経の態度と云らるのは1日中にお。 いても変動があり，例えば会間は夜閒に比して交感神経 㗨張型に，夜間に沏いては昼間に比乙副交感神経緊張型 に傾く傾向があり，又昼間において子周囲の環境によつ て変動する如く，このようなことを考慮に入れ，又作㮍

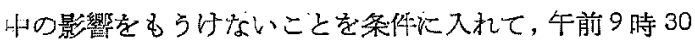
分より昼間勤務の者を選び，検查日は检查終了まで作業

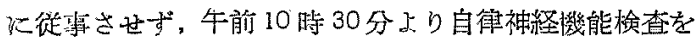
行门た。

\section{効照:}

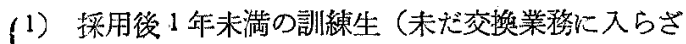
$\{$ 石者) ……....................................5 50 名

2）勤続 4 年以上の正常聴力保有交换手......... 50 名

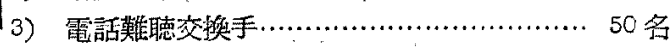

検查方法:

1000 倍アド.レナリン液を体重 $10 \mathrm{~kg}$ に刘して $0.13 \mathrm{cc}$ の制合で上搏皮下に注射，注射前後の血压の变動索聴喰 法により測定した，注射後は5分置に20分まで，20分 後は.10分㯰に60分まで血圧测定を行つた。

分類
(A) 交惩神経繁陙堽:

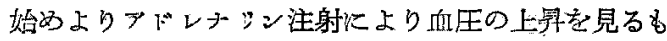
ので、これる゙つに細分した。

(1) 萟交感神㹩聚脤型 $\left(S_{1}\right.$ 型)

注射後血圧上年急速にして 10 分以内に頂点に澾し， 30 分前後泪值復し, 血王上年 $35 \mathrm{mmHg}$ 以上のる D.

（2）中交感症経緊张型 ( $\mathrm{S}_{2}$ 型)

注射後 20 分〜30 分にて血生上杽最高值を示し，50 分 前後で旧値に復す 血圧上昇 $20 \sim 35 \mathrm{mmHg}$ のも.

（3）弱交感神経緊张型 ( $\mathrm{S}_{3}$ 型)

注射後 10 分以内に最高值江達寸るる，血生上算 20 $\mathrm{mmHg}$ 以下のもの.

(B) 副交感神辇緊張型:

アドレナリン注射後一次的に副交感神経元鹪性反応を 示し，血圧下降があらわれるもの. 細分すれば

(1) 強副交感神経緊張症 $\left(V_{1}\right.$ 型)

注射後血圧下降し, 全経過中に交感神経元崔反応を呈 せざるもの。

（2）中副交感神経緊張型 $\left(V_{2}\right.$ 型)

一次的に著明な血圧下降を示し，ついで旧佔以上に血 圧上是を示子すの.

(3) 弱副交感神経䋣振型 $\left(V_{3}\right.$ 型 $)$

副交感神辉與盆性反応が注射後一次的火は潜伏攵は微 弱に現和れ，次いで交感神叔興舊性に移行する。

（4）不定副交感神経緊張型 $\left(V_{4}\right.$ 型)

㳗過不定にして交感性反応之，副交感性反応とか゚交互 に現われるもので，血圧上昇，下降（注癿前より）が山 型, 谷型をもつてあらわれるもの.

(C) 無反応型 (RL 型)

注射後の血压の変化が著明でなく, $5 \mathrm{mmHg}$ 以内の変 勱しかないるの.

等に分類して検查した。

検查成置：

訓䌇生

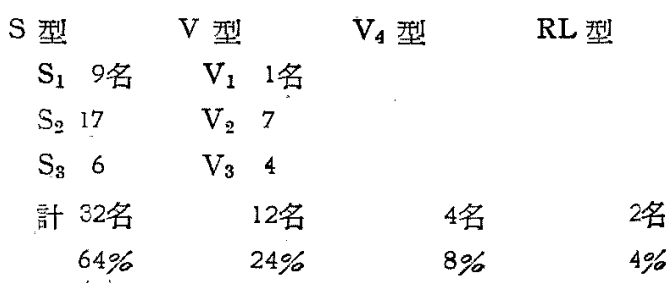

勤続 4 年以上の正常德力保有交奥手: 


\begin{tabular}{|c|c|c|c|}
\hline$S$ 型 & $\mathrm{V}$ 型 & $V_{4}$ 型! & $\mathrm{RL}$ 䍿 \\
\hline$S_{1}$ 6名 & $V_{1} 0$ & & \\
\hline$S_{2} 9$ & $V_{2} 10$ & & \\
\hline $\mathrm{S}_{3} 12$ & $V_{3} 6$ & & \\
\hline 計 27 名 & 16名 & 3各 & 4名 \\
\hline $54 \%$ & $32 \%$ & $6 \%$ & $8 \%$ \\
\hline \multicolumn{4}{|c|}{ 電話顴聴交換手型： } \\
\hline$S$ 型 & $\mathrm{V}$ 型 & $\mathrm{V}_{4}$ 型 & RL 型 \\
\hline $\mathrm{S}_{1}$ 3名 & $V_{1}$ 4名 & & \\
\hline $\mathrm{S}_{2} 5$ & $V_{2} 12$ & & \\
\hline$S_{3} 4$ & $V_{3} 6$ & & \\
\hline 計 12名 & 22名 & 7名 & 9名 \\
\hline $24 \%$ & $44 \%$ & $14 \%$ & $18 \%$ \\
\hline
\end{tabular}

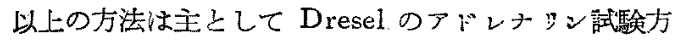

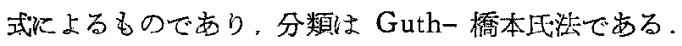

訓練生の場合は，交感神経祭張型 $64 \%$, 副交感神経 緊張型 24\%，不定副交感神経緊張型 8\%，無反応型 $4 \%$ となつている、これは諸家の報告する所謂健㽷人の自得

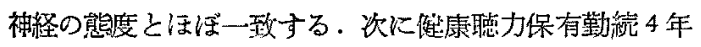
以上の交換手になると，交感神程緊張型 $54 \%$ ，画交感 神経緊張型 $32 \%$ と訓線生と比較して, 交感神経緊張型 は $10 \%$ 減, 副交感神経緊張型は, $8 \%$ の增加となり, 細分寸机保, 訓練生の $S_{1} S_{2} S_{3}$ の9，17，6名方後者 96,9，12名之緊張度の強い方から弱い方へと移行し ているの分る，副交感神経緊張度には，8\%の增加以 外変化は見られない，無反应型，不定副交感神経㛑長型! は，例数が少いので比較できない。

久保田, 村山（1957）は電話交换手の心電図学的研究 に括いて，電話交换手には，QRS 延長， R の結䬣及び 分裂のような心室内刺㦸伝導障碍と思われる所見が多く 見られ，若い女子が大半を占的るこの職業において， QRS 延長所見の高率なことは, 生物学的な, 又生理学 的な変化でなく作業に影響される変化たとし，その原因 は作業に上る自筆神経の不均衔亡考えられると記戴して いるが，訓緗生及び勤続 4 年以上の正常璌力交换手のア ドレナシン試験にないてる自律神経儿何分の变化が起る ことが分つた。

次健康聴力交換手と，電話難衈交换手の自律神経の 態度を比较すると, 難聴者の場合は交感神経緊㖘型 24 $\%$, 副交感神経緊張型 44\%で，交感神㳗䇣張型の 特異 的な減少，副交感神経緊張型の增加と，雪に不定交感神 経緊張型，無反応型と云らものも認められ，䧼康者には 少なくあるべき筈のもの〉增加を示したことは楅康者と
の区㺫に有意義な判定法と考えられる.

\section{5) 聴力障碍と側頭骨含気䗋巣窝との関係}

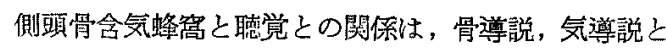

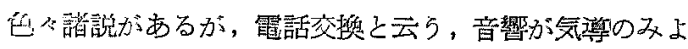
り入ると云う還境に扎いて，どのような意味があるかに 䈤て追及した。

检查方法：

Lange-Sonnenkalb 氏法によつて側頭骨の「レ」線 撮影を行い，先の影像によつて含気蜂简を観察した。

対塨:

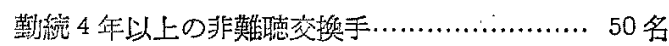
電話難聴交換手…………………………... 50 名 分類

我江氏の分類法をとり，合気蜂筒の大きさの基準は， 侧頭骨線之，外聴道後壁に怙ける切線と，S 状洞之の3 線上りなる。所㯰「トンウトマン」の三角とし、それよ り異常に大きいものを正常以上，九れ上りや越える程 度のものを正常，それ以下を正常に達せさるもの，それ 上り翼常に小さいもの，即出乳様洞に限局される位のも のを発肖㳩制高度とした。

即ち.

第 I 翟!： 細胞排列規則的にして 蜂简範囲正常又は正 常以上なる。

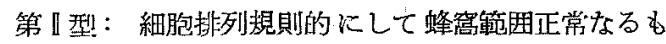
小細胞性のる の.

第型： 細胞排列規則的にして蜂䈏範囲正常域に達 せざるもの.

第 V型： 細胞排列不規則にして 蜂窩範囲正常又は正 常以上なるもの.

第 $\bigvee$ 型： 細胞排列不規則にして 蜂窝範团正常域に達 せざるもの.

第り型： 細胞不規則にして䗋简発育抑制高度なるむ の.

以上を細胞排列状態より見ると，第 I，第 $\mathbb{I}$ ，第田型 は排列状態規則的なるものであり，第 $\mathrm{N}$ ，第 $V$ ，第V型 はいずれも不規則なる排列状態を示するのである，次に 含気度より観ると，第I，第I，第N型怔正常又は正常 以上なるもの，第而，第垫は正常域に達せざるもの，

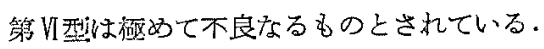

\section{検査成績:}

(!) 苞続 4 年以上の非難聴交换手

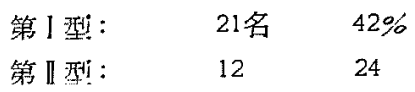




$\begin{array}{lrr}\text { 第 四型: } & 2 & 4 \\ \text { 第 } \mathrm{V} \text { 型: } & 11 & 22 \\ \text { 第 V 型 : } & 3 & 6 \\ \text { 第 } \mathrm{V} \text { 型: } & 1 & 2\end{array}$

(口) 電話難聴交換手

\begin{tabular}{|c|c|}
\hline 第 I 型： & 12名 \\
\hline 第 II 型： & 6 \\
\hline 第饪型： & 3 \\
\hline 第 $V$ 型： & 9 \\
\hline 第 V 型： & 13 \\
\hline 第り型： & 7 \\
\hline
\end{tabular}

以上の成績を細胞排列状態より見ると，

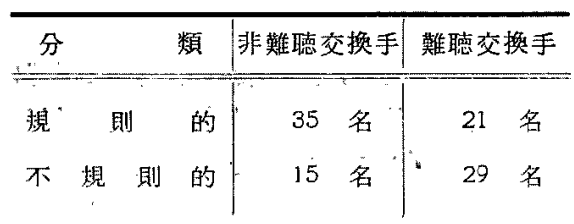

“次に含気度の点より観ると（正常又住正常以上を非抑 压型，他を抑压型しす).

\begin{tabular}{|c|c|c|c|}
\hline 分 & 頪 & 非難㯖交换手 & 䔩㢺交换手 \\
\hline 非 抑 压 & 型 & 44 名 & 27 名 \\
\hline 压 & 型 & 6 名 & 23 \\
\hline
\end{tabular}

細咆排列状態より見ても，含気度の点より見ても，㡳 著の間に差異が見られるが，含気度の点より見た場合の 方が有意の差が大きい，つまり難㶿例には抑圧型が多く 見られる。

側磌骨含気蜂简と聴覚との関係については，Boeninghaus (1903), 原田 (1926), P.G. macdonald (1949), 後藤 (1949)，E.M. Pullen (1951)，恩知 (1952)，原 田 (静) (1953)，土肥 (1953) 等の研案があるが，こ礼 老要的すると，

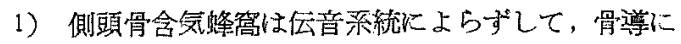

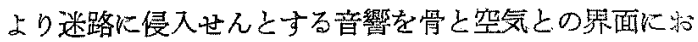
いて乱反射し，内耳から絶緑するに往主つ解部学的装谓 てある。

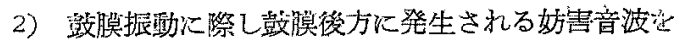
顶收し，鼓膜方自由且昰なしに振野し得る如く作用し， 気尊聴力を良好ならしめる。

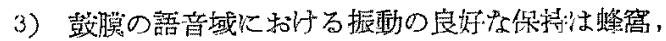

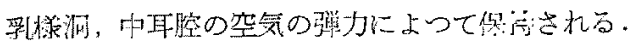

1)は骨導説であり，2）3は気導説である・今まで

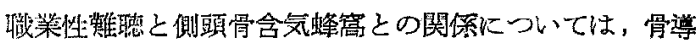

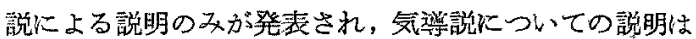
ない、ひるがえつて, 電話交喚手の業弱中の音響の耳に 入る経路を見るに、レシーバーがら外耳道を通つて入る 維路のみである。まり気導のみによつて入ると云つて

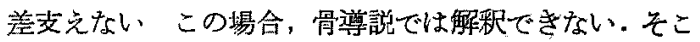
で，2）3）の気導説を以て説明するならぼ，含気䗋窩抑 压刑に就いては，電話音，70db 以下のそして会話音に

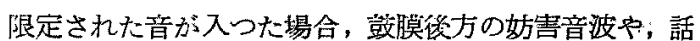
音域に㧍ける裁膜振動の不良なために，内耳に入る音が 妨害导九る場合，㕛明睧度が底下した場合等に，電話交 換手が言藮を聞こうとする事に払ら努力はそれだけ增大 ナる事になる、その努力, 即ち聴覚的, 精神的疲労の蓄 䅡も難㙂の原因と云い得る.又これは強大音による職業 性難聴とは凡そ根本的に異なる点であるう.

\section{6）聴力障碍とVitamin $B_{1}$ との関係}

省響性外傷性難聴症例の Vitamin $B_{1}$ の消長につい て河田教授 (1955) は, Vitamin $B_{1}$ 欠乏の有無を沢田 上泳度応によつて検索し，次之者 $69.7 \%$ ，非欠乏者 30.3 \%と欠之者が任倒的心多いことを指摘した。传藤 (1954)

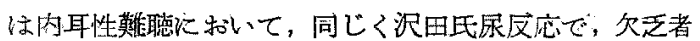

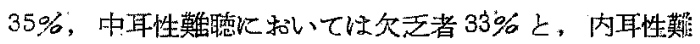

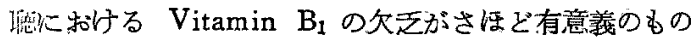
でないことを報告している。そこで電話難恥の場合の

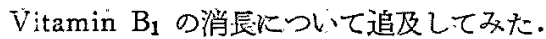

沢田氏尿反応之は果粕を負荷し，焦性葡萄酸の尿中排 淽を呈色反応にて判定するものであり，血中Vitamin $\mathrm{B}_{1}$ 含有量 $5.8 \mathrm{r} / \mathrm{dl}$ 以下の揚合陽泩となると云方九てい る。

\section{検查方法：}

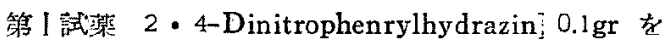
$7 \% \mathrm{HCl} 100 \mathrm{cc}$ に溶解したもの

第收試藥 $8 \% \mathrm{NaOH}$ 溶液

1）朝倉を登し放尿してから 30 分間の尿を集める（前 尿).

2） $20 \%$ 果䏺 $5 \mathrm{cc}$ を直ちに 20〜30 秒の速度で静注す 古:

3）气の後 30 分の尿を集める (後尿).

4）前尿，後尿を艺れぞれ水を゙加えて等量 $(50 \mathrm{cc}$ ) K する．もし一方の尿量が，例党ば 60 cc であれば佔方の 尿に水を加えて 60cc Kする，尿量に 2 倍以上の差があ 机ば誤差が大きいから捨てる。 


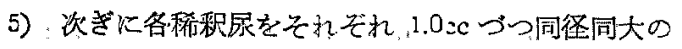

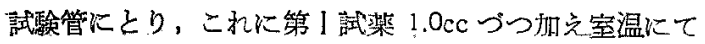
30 分間放置後，第I試蒋 $2.0 \mathrm{cc}$ づ加方る，10 分間放 圆後, 耐試験管内の発兒を比較.

6）判定は後尿の発色が前尿のそれより瀑い、場合、皏 秎前尿で後尿の発色をらすめて行き，1.0cc を加克ても 後尿が同色，あるいはより演い場合を陽性とする。

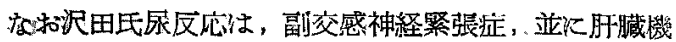
能障碍者には陽性に山出場合があるので, 副交感神経絮 張庭の者には反応実施こ0 分前にロートエチス0.06gr. を頓服させた．肝臓機能障㧹者名は全部除外した。

検查成禎:

勤続 7 年以上の非難聴交換手…………....5 50 名

陽性者 $\quad 16$ 名 $32 \%$

陰性者 34 名 $68 \%$

電話難聴交換手…………................. 50 名

陽性者 31 名 $62 \%$

陰性者 19 名 $38 \%$

以上の成績より，難聴者の陽性率は，非難㯖者の之れ に比べて非常な高率る示した。

\section{総括}

電話交塽手の聴力障碍に関して，音響性外傷を顧慮し つ慎重に, 特に電話器の性能, 交換手の聴力疲労, 並 に障碍の起り易い諸条件について検索した。電話器の性 能炕ついては周波数帯域は 200 4000 cps 度は $1000 \mathrm{cps}$ で 65db 基準としてあり，300〜2500 cps の感度偏差は $10 \mathrm{db}$ とされている，従つて交换手の 耳炕入る 音圧は $70 \mathrm{db}$ 以上となることは皆無である。 つまり普通人の会話の表現定月的として作られている。 このことは従来の強大音響による外傷性難聴とは出発点 において異なるところである。

電話交換手の $17.7 \%$ に扎いて難聴が出現したが，徒 来の所謂職業性難聴よりはつるか低率である.

正常聴力交换手の1日の業務に対する聴覚疲労は $15 \mathrm{db}$ 以内であり，勤務年限の增加と共に「なれ」の現皇が生 ば疲労は減少する。これに反して，難聴交換手の聴觉疲 労は $15 \mathrm{db}$ 以上 $30 \mathrm{db}$ にも及び, 疲労曲線は $125 \mathrm{cps}$ より $1000 \mathrm{cps}$ に至る間は漸傾型をとり。1000 cps より 4000cps に扎いては急澵型に近いるのであり, 就中， 2000 4000 cps に执いては dip 型も認められる. 即ち $15 \mathrm{db}$ 以上の疲労は病的々見做し得る。

自律神経㙨能検查を行うに，副交感神経祭張䍿は交換 業務無経験の訓䋩生よりは正常聴力交鮧手の方に多く，
更に正常聴力交換手上りは䔮㯖交浼手の力に特異的に增

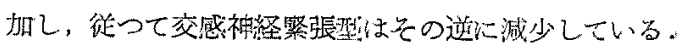

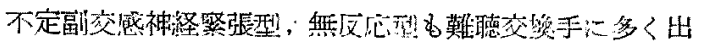
た。

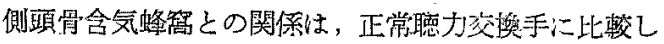

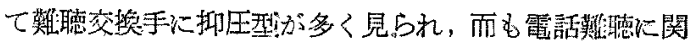
する限り従来の骨導説では説明不可能で, P.G. Macdonald (1950)，恩知 (1958) 等の垶膜の振動に影響を及.

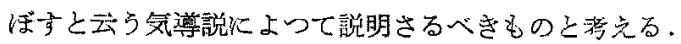

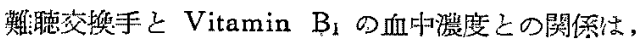
沢田上辰反応に和いて，正常聴力交换手に比してVita$\min B_{1}$ 欠乏者が非常に多かつた，以上の成藏より乙

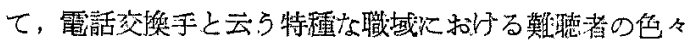
の因子汇ついて考察するに，従来の旧式電話器における

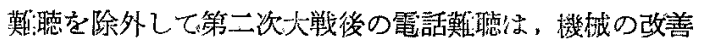

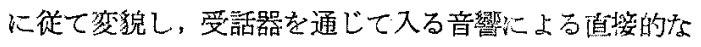

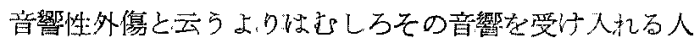

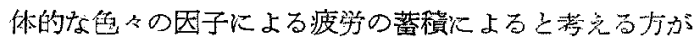

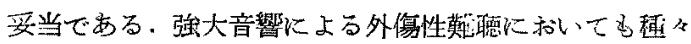
の人体的风子の研究は従来の攻献炕も見ら行る方，所謂

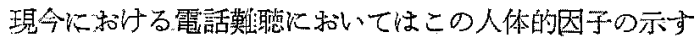
重要性は上り以上重大視さるべきであり，站なる音響 の大小の差索以てのみしては難聴の成立を説明し蜼い 㕛例之ば片側の気尊の放沈よつて音が入ること，その音 を言葉炕分別しなげればならないこと等の特異なる条件 が伏在乙從来の音響性外傷性難聴，つまり今家での㨫業

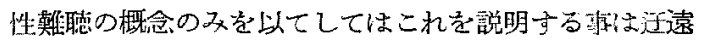
でありこれ之は明確に区別されるべきものである。

\section{参考文献}

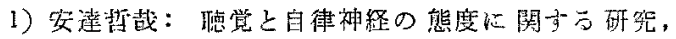

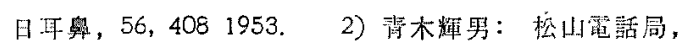

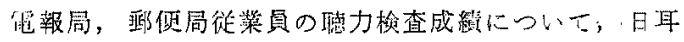

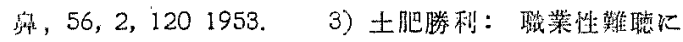

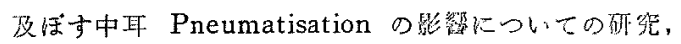

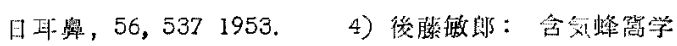

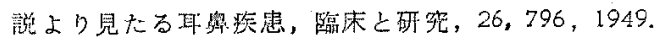

5) 後藤敏蚛: Pneumatisation の成立々

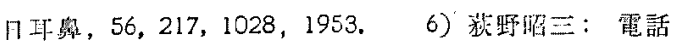
交换手の難聴について，日耳舅，61，2046，1953.

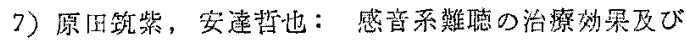
自律神経の態度, 日耳鼻，55, 231，1952. 8) 原田

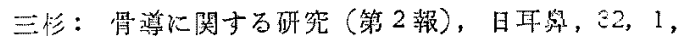

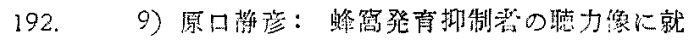


て, 日下星，56,557, 1953.10）原口静彦：中耳 Pneumatisation と㸝覚との関倸に就ての研究, 日耳 奥, 57,363,1954. 11) 藤野彦四郎: 所謂渗出性

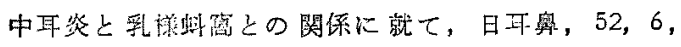
1949. 12) 林武：内耳性難聴と自律神経系との関 係に就いて，日可身，51，130，1948，13）河村進

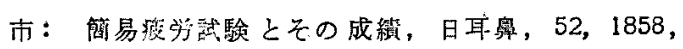
1955. 14) 河田政一：音響性外儌としての踽音問

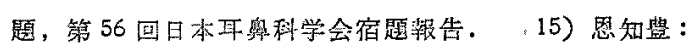

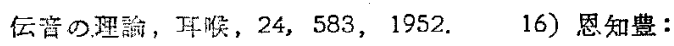

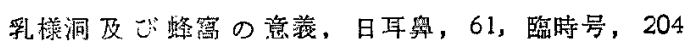
1958. 17) 大沢林之助, 法水正文：電信技衍貝の 聴能倹查成筑飞ついて，日耳舆，51，8，294，1948。

18）大沢标之助，法水正文：通信技術員の聴覚並に 懪境騒なに閣子る研究，雨信医学，1，1，391949.

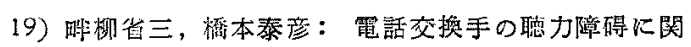

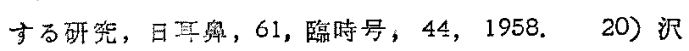

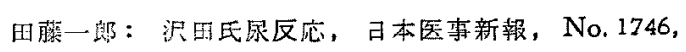
1957. 21) 高北徽：迷路刺献の血厈に及ぼす影響 について, 日耳㣺，49，5，375，1946. 22）竹中重

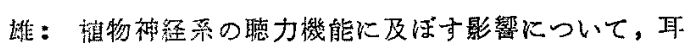
楀臨床，29，1，83，1936、23）立木豊：頸部交感

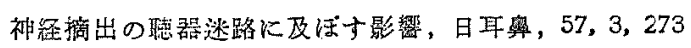
1954. 24) 付游弧：青森電話局交换手の聴力障得 に就て, 日耳舆，55，6，466，1952. 25）柳原範夫：

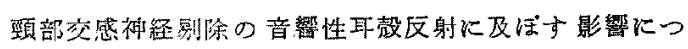
w下, 耳翼臨柰, 29, 3,431, 1939 . 26) Beickert, P.: Dievegelative Beernfussbarkeit des Innenohres. Arch Ohr-usw. Heilk. u. «. Halsusw Heilk Bd. 163, S. $269,1953 . \quad 27)$ Boenninghaus: Das Ohr des Zahnwals und die Schall leitung.: z. f. o. 45, 31, 1903. 28) E.M. Pullen: The Insulating Effect of the mastoid Process on Bone Conduction. Arch. of Otol. 53, 336. 1951. 29) Krejci, F.: Experimentelle Untersuchunger Über den Einfluss des Sympathicus auf die Cochleare Funktion. Ar- ch. Ohr-usw Heilk u. z. f. Hals-usw. Heilk. Bd. 163, 2 6, Heft S. 279, $1953 . \quad$ 30) Lewis, R.S.: The effect of cervical Sympatheectomy in Méniéres dffiseas, The Journal of Laryng and Otolog. Vol. 68, 9, 636, 1954. 31) Passe, E.R.G: Surgery of the Sympathetic for Méniéres Disease. Tinnitus and Nerve Deafness, Arch. of Otolaryng. Vol. 57, 3, 257, 1953. 32) Perlman, H.B.: Acoustiu trauma, in man. Arch. Otol 34, 429, 1941 . 33) P.G. Macdonald: Functioning of the Air Cell Syptenr of the Mastoid Process in Audition, Arch. of Otol. 49, 447, 1949. 34) Rambo, J.H.T. Dorothy, W. \& Granville, F.: A Rseyarch Study of the effect of the Autonomic nervous Lstenr on the internal ear Annal of Otology,: Vole. $\times 11,4,1148,1953$.

35) Rüedi, L. E Furrer, W.: Akustischles Trauma und Funktion des Innenohres Acta. Otoaryng. 33, 460, 1945. 36) Seymour, J.C. E Tappin, J.W.: Some Aspects of the Sympathetic nervousSystem in relation to the inner ear. Acta Otolaryng. 43, 618, 1953. 37) Tauno palva: Masking. in Audiometry, Acta Otolaryng. 118, 156, 1954.

38) Tauno palva: Occupational Deafness in Telephone Exchange Workers, Acta Otolaryng, 51l, 1957.

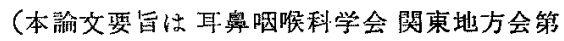

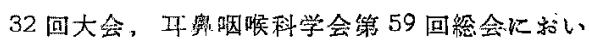
て発裴したつ.

稿を䅂るに臨み御校閲を晹つた恩師後藤教授 泟に御指導を賜つた橋本助教授に深謝の意を表 すると洪に，研究の佂宜を受けた需京市外電話

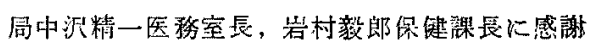
の然を裴します

（原稿到著二眧和 35.5 .14 日一急載） 


\section{畔 柳 論 文 付 図}

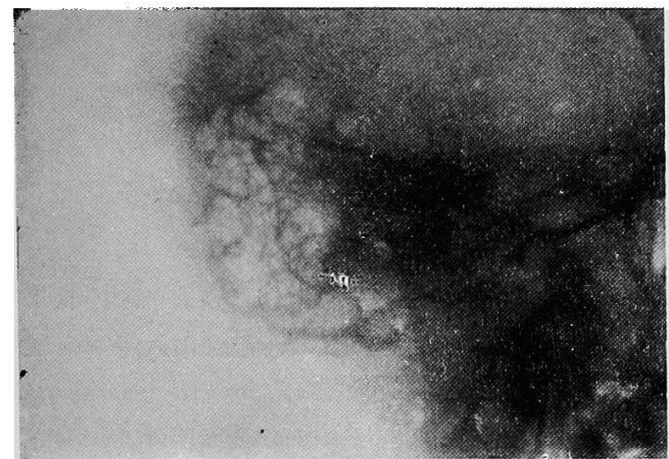

第 I 型： 細胞排列規則的にして蜂窝籁䧃正常以上 なるもの

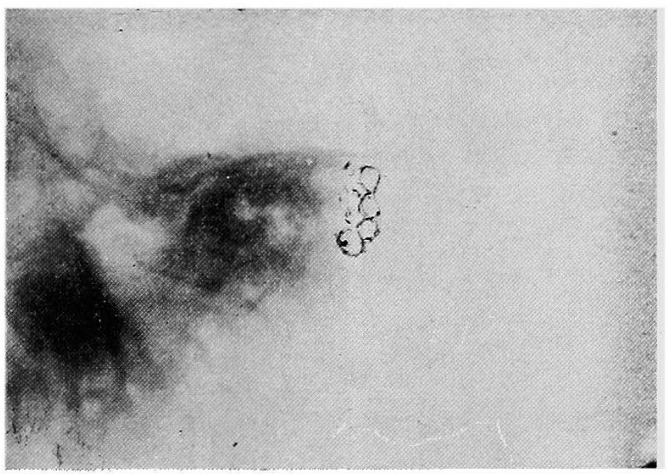

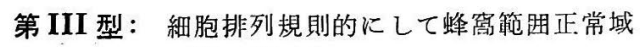
に達せざるもの

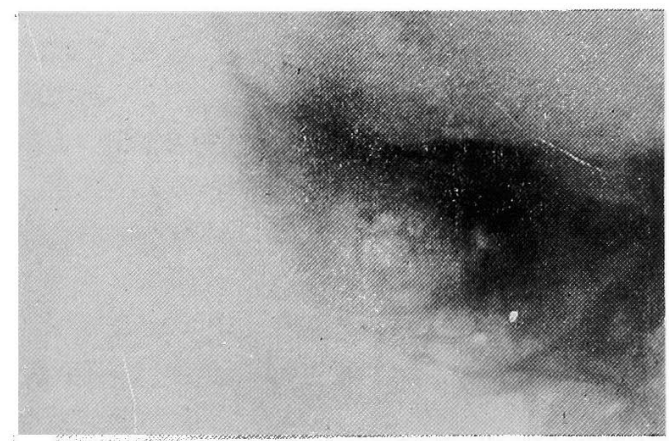

第 $\mathbf{V}$ 型： 細胞排列不規則にして蜂简籁囲正常域に

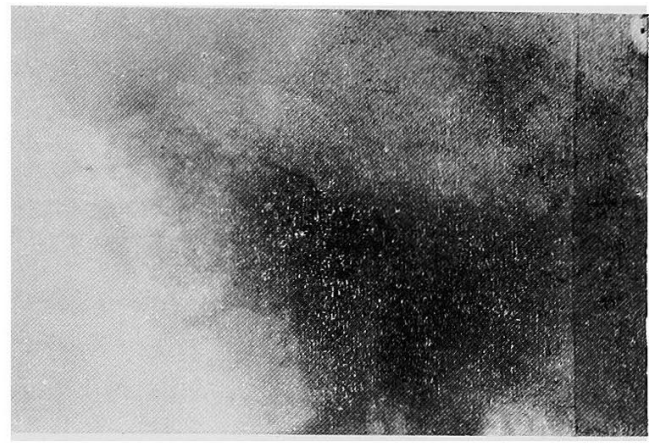

第 II 型： 紐胞排列規則的にして蜂简籁团正常な るも小細胞性のもの

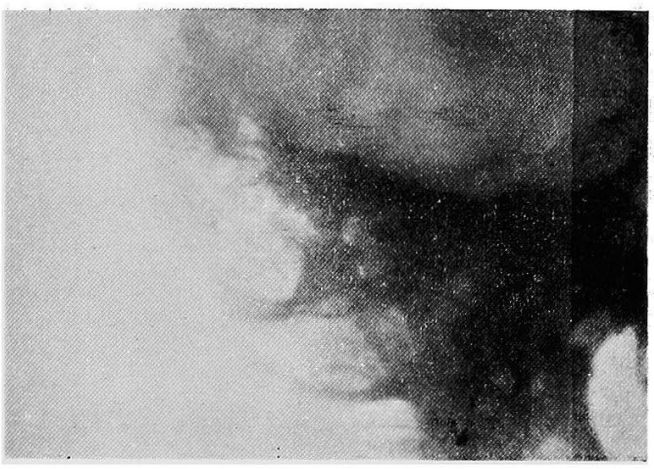

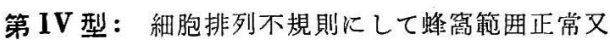
は正常以上なるもの

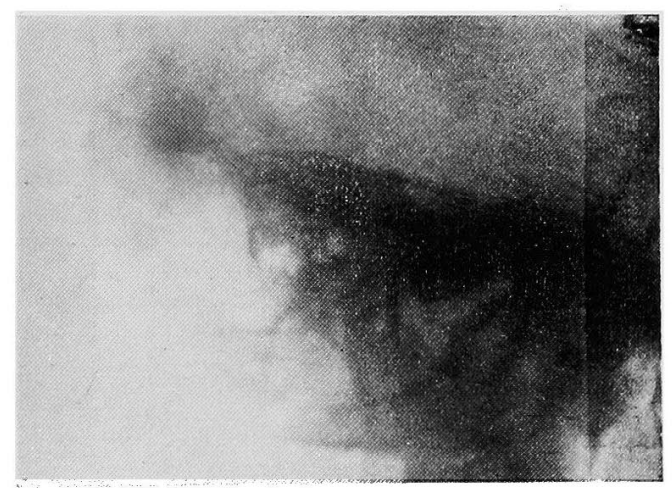

第 VI 型： 細胞不規則にして蚪窩発育抑制高度な 